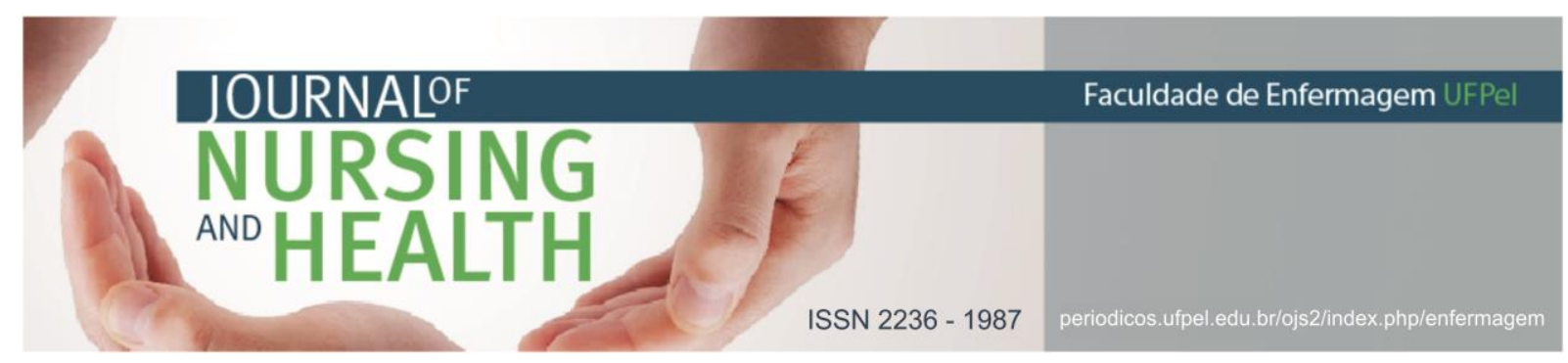

ARTIGO ORIGINAL

\title{
Overweight and obesity among individuals with mental disorders in southern Brazil
}

\author{
Sobrepeso e obesidade entre pessoas com transtorno mental no sul do Brasil \\ Sobrepeso y obesidad en personas con trastorno mental en el sur de Brasil
}

Jardim, Vanda Maria da Rosa ${ }^{1}$; Treichel, Carlos Alberto dos Santos²; Kantorski, Luciane Prado ${ }^{3}$; Silva, Marcos Daniel; Bernini ${ }^{4}$, Carolina Reinbrecht; Secchi ${ }^{5}$, Thais Leite ${ }^{6}$

\begin{abstract}
Objective: to identify the prevalence of overweight and obesity among users of the Centers for Psychosocial Care in southern Brazil. Methods: it is a cross-sectional study, held in 2011, which had the participation of 1.267 subjects. In order to track the occurrence of overweight and obesity, participants had their body mass index calculated based on self-reported information on weight and height. Descriptive statistics was used in addition to analysis of strata conducted using the Chisquared test. Results: adopting as reference for categorizing the Body Mass Index the Brazilian guidelines for obesity (2009-2010), this study found the prevalence of overweight and obesity of $34,8 \%(n=441)$ and $21 \%(n=266)$, respectively. Conclusions: higher prevalence of obesity was observed in females $(23.7 \% n=171)$, aged between 31 and 45 years $(25.8 \% n=134)$, and diagnosed with bipolar disorder $(31.2 \% n=45)$.
\end{abstract}

Descriptors: Obesity; Body mass index; Mental health; Community mental health services.

\section{RESUMO}

Objetivo: identificar a prevalência de sobrepeso e obesidade entre usuários dos Centros de Atenção Psicossocial da região Sul do Brasil. Métodos: estudo transversal, realizado no ano de 2011, com a participação de 1.267 sujeitos. Para rastreio da ocorrência de sobrepeso e obesidade, os participantes tiveram seu Índice de Massa Corporal calculado com base nas informações autorreferidas de peso e altura. Foi utilizada estatística descritiva além de análises entre estratos utilizando-se teste de Chi quadrado. Resultados: adotando como referência para categorização do Índice de Massa Corporal as diretrizes brasileiras de obesidade (2009-2010), rastreou-se uma prevalência de sobrepeso e obesidade de $34,8 \%(n=441)$ e $21 \%(n=266)$ respectivamente. Conclusões: elevada prevalência de obesidade foi observada em indivíduos do sexo feminino $(23,7 \% \mathrm{n}=171)$, com idade entre 31 e 45 anos $(25,8 \% n=134)$ e com diagnóstico de transtorno bipolar $(31,2 \% n=45)$.

Descritores: Obesidade; Índice de massa corporal; Saúde mental; Serviços comunitários de saúde mental.

\footnotetext{
${ }^{1}$ Enfermeira. Doutora em Enfermagem. Docente da Universidade Federal de Pelotas, Pelotas, RS, Brasil. Email: vandamrjardim@gmail.com http://orcid.org/0000-0001-8320-4321

2 Enfermeiro. Mestre em Enfermagem. Doutorando em Saúde Coletiva da Universidade Estadual de Campinas, Campinas, SP, Brasil. Email: carlos-treichel@hotmail.com http://orcid.org/0000-0002-0440-9108

${ }^{3}$ Enfermeira. Doutora em Enfermagem. Docente da Universidade Federal de Pelotas, Pelotas, RS, Brasil. Email: kantorski@uol.com.br http://orcid.org/0000-0001-9726-3162

${ }^{4}$ Médico. Médico da Família na Prefeitura Municipal de São Francisco do Sul, São Francisco do Sul, SC, Brasil. Email: marcosdaniel_mds@hotmail.com http://orcid.org/0000-0003-2361-4067

${ }^{5}$ Médica. Residente em Ginecologia e Obstetrícia da Universidade Federal do Rio Grande, Rio Grande, RS, Brasil. Email: carolina_bernini@hotmail.com http://orcid.org/0000-0002-2554-291X

${ }^{6}$ Médica. Residente em Neurologia do Hospital de Clínicas de Porto Alegre, Porto Alegre, RS, Brasil. Email: thaislsecchi@gmail.com http://orcid.org/0000-0001-5214-7037
} 


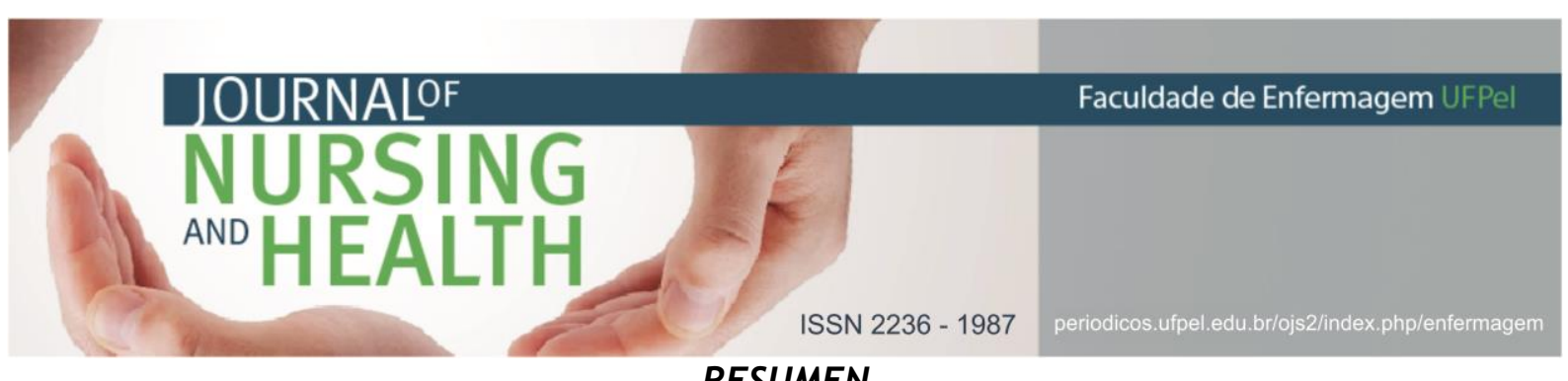

RESUMEN

Objetivo: identificar la prevalencia de sobrepeso y obesidad entre usuarios de los centros de atención psicosocial de la región sur de Brasil. Métodos: estudio transversal, realizado en el año 2011, que ha tenido la participación de 1.267 sujetos. Para el rastreo de sobrepeso y obesidad, los partícipes tuvieron su masa corpórea calculada con base en las informaciones auto referidas de peso y altura. Fue utilizada la estadística descriptiva y también el análisis entre estratos utilizando el test de Chi cuadrado. Resultados: adoptando como referencia para categorización del índice de masa corpórea las directrices brasileiras de obesidad (2009 - 2010), este estudio rastreo una prevalencia de sobrepeso y obesidad de $34,8 \%(n=441)$ y $21 \%(n=266)$ respectivamente. Conclusiones: la mayor prevalencia de obesidad fue observada en individuos ser sexo femenino $(23,7 \% n=171)$, con edad entre 31 y 45 años $(25,8 \% n=134)$ y con diagnósticos del trastorno bipolar $(31,2 \% n=45)$.

Descriptores: Obesidad; Índice de masa corporal; Salud mental; Servicios comunitarios de salud mental.

\section{INTRODUCTION}

Within the current context of care of individuals with mental disorders in Brazil, the Centers for Psychosocial Care have been featured in the reorganization of mental health network in the country. This service, regulated by the Ministry of Health, ordinances $336 / 02$ and $2.841 / 10$, aims to provide clinical care and psychosocial rehabilitation to individuals with mental disorders within its territory.

Several evaluation studies have shown the potentiality of a care model based on community-based services, such as Centers for Psychosocial Care, when caring for individuals with mental disorders, showing their potential for reintegration and psychosocial rehabilitation.1-2 However, instead of fulfilling the role of one health care facility among a net of services, CAPS is often seen as the sole provider of care to those living with a mental disorder.3-4

This perspective has negative repercussions on the model proposed by the Brazilian psychiatric reform movement as it contributes to the perpetuation of old practices that focus on the diagnosis of the subject and not the subject with a diagnosis.
Previous studies have indicated some factors associated with this reality, from the feeling of lack of training by primary care professionals to a lack of communication between mental health services and others services health. 56

As consequence of this scenario, the disparities in health care experienced by individuals with mental disorders increase, becoming worrisome, as there is evidence in literature indicating that this population presents mortality rates two to three times higher than the general population7, and life expectancy reduced in 10 to 30 years. 8

Among the factors associated to above mentioned aspects, studies7,9 have indicated issues, such as the high prevalence of hypertension, diabetes, dyslipidemia and heart diseases, directly linked to obesity, which among people with mental disorders is favored by the low rate of physical activity, unhealthy diets and obesegenic effect of medications, such as antipsychotics, benzodiazepines, and tricyclic antidepressants, commonly prescribed for this population.10 


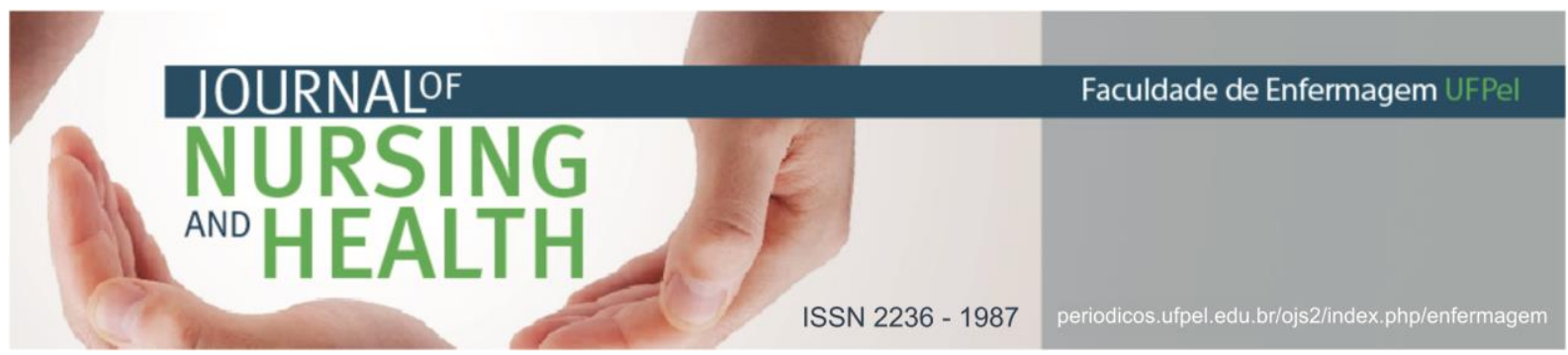

In this context, some authors10-

services, divided in a ratio of $66 \%, 32 \%$ 11 have been devoted to exploring the prevalence of obesity in people with mental disorders. However, the approach to this theme is still recent and scarce, with few studies abroad and little or no record previously held in our country.

Thus, in order to collaborate with the exploration of the theme in the Brazilian context, this study aims to identify the prevalence of overweight and obesity among users of Centers for Psychosocial Care in Southern Brazil.

\section{MATERIALS AND METHODS}

It is a cross-sectional study, clipping of an evaluation research held in 2011 on Centers for Psychosocial Care from southern Brazil (CAPSUL II). The study took place in 40 services distributed in the states of Rio Grande do Sul, Santa Catarina and Paraná, and involved users, relatives of users, staff and coordinators.

This study is based on selfreported information, so, for this clipping, 1.267 users were considered and accessed by the survey, who could report their data on weight and height.

The data collection was carried in 40 Community Mental Health Services (named CAPS), type I, II and III among three states of Southern Brazil (Paraná, Santa Catarina and Rio Grande do Sul). In agreement with the regional health planning principles, each state is split into health regions. In this sense, the states of Paraná, Santa Catarina and Rio Grande do Sul, count respectively with 6,9 and 7 health macro-regions each. The amount of CAPS type I, II and III that was available in the three states during the research corresponded to 232

and $2 \%$ to CAPS type I, II and III respectively. In the state of Paraná, during the research, there was 43 CAPS type I, 23 CAPS type II and 2 CAPS type III. In the state of Santa Catarina, during the research, there was 45 CAPS type I, 12 CAPS type II and 2 CAPS type III. In the state of Rio Grande do Sul, during the research, there were 65 CAPS type I, 40 CAPS type II and no CAPS type III.

For selection of the services included in the study, it was respected the proportionality of services in each state, this way, it was included in the sample 12 services from Paraná, 10 services from Santa Catarina and 18 services from Rio Grande do Sul. First, it was decided to include intentionally all CAPS type III (4) available in the three states and later it was adopted drowns that take account the health regions existing in each state and the proportion of CAPS type I and II.

The ratio calculation between CAPS type I and II resulted in $67 \%$ and $33 \%$ respectively. Thus, it was decided that the 36 services to be selected should be divided into 24 CAPS type I and 12 CAPS type II. This way, considering the proportionality of services in each state, it was defined the inclusion of 7 CAPS type I for the state of Paraná, 6 for the state of Santa Catarina and 11 for the state of Rio Grande do Sul. In the same sense, it was defined the inclusion of 3 CAPS type II for the state of Paraná, 2 for the state of Santa Catarina and 7 for the state of Rio Grande do Sul.

The draws of the services included in the study were conducted state by state based on the health regions existing in each one. In the 


\section{JOURNALOF \\ NURSING \\ ${ }^{\text {AND }}$ HEALTH}

ISSN 2236 - 1987

Based on the sample calculated,

state of Paraná, which has six health regions and was planned the inclusion of 7 CAPS type I, it was defined that would be drawn one service in each health region, and later, by drawn, it was defined the health region, and a new draw for the 7th service selection to be studied would be carried out. For selection of CAPS type II, a first draw defined the three health regions in which the draws of services would be conducted. Subsequently, were carried the draws in each of these health regions to define the services included in the sample.

In the state of Santa Catarina, which has nine health regions and it was planned the inclusion of 6 CAPS type I, a first draw defined the six health regions in which the draws of services would be conducted. Subsequently, were carried the draws in each of these health regions to define the services included in the sample. Also, for the selection of CAPS type II, a first draw defined the two health regions in which the draws of services would be conducted. Subsequently it was carried the draws in each of these health regions to define the services included in the sample.

In the state of Rio Grande do Sul, which has 7 health regions and it was planned the inclusion of 11 CAPS type I, first it was defined that would be drawn one service in each health region and subsequently, by drawn, it was defined the four regions which would be conduced a new draw for select the 8th, 9th, 10th and 11th services to be studied. For selection of CAPS type II, it was decided that would be drawn one service in each health region. the study sought to apply the questionnaire in 1600 users. For the prevalence, the sample calculation considered an estimated frequency of $50 \%$ with a margin of 3 points and alpha (a) of $5 \%$, resulting in the need of $N=$ 1066. For the association, there was considered a sample' power of $90 \%$ with $95 \%$ confidence, ratio of nonexposed / exposed of 2:1, relative risk of 1.3 and a prevalence of $40 \%$ in nonexposed. So, the sample indicated was $\mathrm{N}=1038$. However, in order to consider expected losses and confounding factors control, there was added in the higher indicated $\mathrm{N}(\mathrm{N}=1066) 50 \%$ of individuals.

The selection of respondents was carried out through non-probability sampling. All the users who attended the service during the data collection (period of one week) were invited to participate of the study. The percentage of losses in the users' relatives sample was $20,8 \%$, related to denials and difficulties in responding the questionnaire.

Data collection was performed by 40 interviewers and previously selected and qualified by a training of 40 hours held by the coordinators of the research. Quality control was carried out in the encoding of data collection instruments; in the review conducted by supervisors to receive the questionnaires; in the replication of $5 \%$ of the interviews.

The entry of data in the database was made through double typing in the between the data were compared and evaluated. The same database was used for necessary corrections. software EPI-INFO, differences 
The outcome variable of this study alludes to the categorization of individuals according to their Body Mass Index (BMI) conforming to the Brazilian guidelines for obesity (20092010), namely: underweight $(<18,5 \mathrm{k} /$ $\left.\mathrm{m}^{2}\right)$, normal weight $(18,5$ to $\left.24,9 \mathrm{k} / \mathrm{m}^{2}\right)$, overweight $(25,0$ to $\left.29,9 \mathrm{k} / \mathrm{m}^{2}\right)$ and obese $\left(30,0 \mathrm{k} / \mathrm{m}^{2}\right.$ or more). BMI was calculated as the ratio of body weight (in kilograms) by the square of height (in meters).

The independent variables considered for comparison were gender (male, female), age (18-30; 31 $45 ; 46-60 ; 61$ and over), diagnosis (schizophrenia, depression, bipolar disorder, other, ignored), hypertension self-reported (yes, no) and diabetes mellitus self-reported (yes, no).

Data analysis was performed using the STATA 11 software (Stata corp., College Station, USA) and IBM
ISSN 2236 - 1987

SPSS Statistics. Descriptive statistics was used, in addition, to analyze of strata conducted with the Chi-squared test. It was adopted as significant a pvalue $<0.05$.

The study protocol was approved under technical opinion number $176 / 2011$, by the Ethics Committee of the Faculty of Nursing of the Federal University of Pelotas following the Standards and Guidelines for the Regulation of Research Involving Human Beings - National Council of Health Resolution 196/9612, the aspects of this study also conform to the National Council of Health Resolution 466/2012.13 Ethical principles were assured by: informed consent; guarantee of right not to participate in the research and anonymity.

\section{RESULTS}

Table 1- Categorization based on BMI according to the selected variables.

\section{Categorization based on BMI}

\begin{tabular}{|c|c|c|c|c|c|}
\hline \multirow[b]{2}{*}{ Gender } & Underweight & Normal Weight & Overweight & Obese & \multirow[b]{2}{*}{$\mathbf{P}$} \\
\hline & & & & & \\
\hline Female & $3.2 \%(23)$ & $40.61 \%(292)$ & $32.4 \%(233)$ & $23.7 \%(171)$ & 0,006 \\
\hline Male & $1.6 \%(9)$ & $43.1 \%(236)$ & $37.9 \%(208)$ & $17.3 \%(208)$ & \\
\hline \multicolumn{6}{|l|}{ Age } \\
\hline $18-30$ years & $4.7 \%(10)$ & $56.1 \%(120)$ & $24.5 \%(52)$ & $14.1 \%(30)$ & $<0,001$ \\
\hline $31-45$ years & $2.1 \%(11)$ & $36.1 \%(187)$ & $35.9 \%(186)$ & $25.8 \%(134)$ & \\
\hline $46-60$ years & $2.2 \%(10)$ & $41.7(185)$ & $36.5 \%(162)$ & $19.4 \%(86)$ & \\
\hline Over 60 years & $1.2 \%(1)$ & $35.3 \%(29)$ & $46.3 \%(38)$ & $17.0 \%(14)$ & \\
\hline \multicolumn{6}{|l|}{ Diagnosis } \\
\hline Schizophrenia & $0.6 \%(1)$ & $39.3 \%(63)$ & $30.6 \%(49)$ & $29.3 \%(47)$ & $<0,001$ \\
\hline Depression & $2.3 \%(9)$ & $38.9 \%(148)$ & $37.1 \%(141)$ & $21.5 \%(82)$ & \\
\hline Bipolar & $2.1(3)$ & $30.5 \%(44)$ & $36.1 \%(52)$ & $31.2 \%(45)$ & \\
\hline Disorder & & & & & \\
\hline Others & $3.3(8)$ & $44.2 \%(108)$ & $34.1 \%(83)$ & $18.4 \%(45)$ & $<0,001$ \\
\hline Ignored & $3.2(11)$ & $48.6 \%(165)$ & $34.2 \%(116)$ & $13.8 \%(47)$ & \\
\hline \multicolumn{6}{|l|}{ Hypertension } \\
\hline No & $2.72 \%(27)$ & $46.98 \%$ (467) & $32.6 \%(324)$ & $17.7 \%(176)$ & $<0,001$ \\
\hline Yes & $1.83 \%(5)$ & $22.34 \%(61)$ & $42.8 \%(117)$ & $32.9 \%(90)$ & \\
\hline \multicolumn{6}{|l|}{ Diabetes } \\
\hline No & $2.59 \%(30)$ & $43.04 \%$ (498) & $34.8 \%(403)$ & $19.5 \%(226)$ & $<0,001$ \\
\hline Yes & $1.0 \%(2)$ & $27.27 \%(30)$ & $34.5 \%(38)$ & $36.3 \%(40)$ & \\
\hline TOTAL & $2.5 \%(32)$ & $41.7 \%(528)$ & $34.8 \%(441)$ & $21 \%(266)$ & \\
\hline
\end{tabular}


The sample consists of 1.267 subjects. Its composition comprised mostly males $(59.24 \% \mathrm{n}=750)$, aged between 31 and 45 years $(39,64 \%$ $\mathrm{n}=502$ ), followed by those aged between 46 and 60 years (35,91\% $\mathrm{n}=455)$.

Adopting as reference for categorizing the BMI the Brazilian guidelines for obesity (2009-2010), this study tracked a prevalence of overweight and obesity of $34.8 \%$ $(n=441)$ and $21 \%(n=266)$ respectively. The individuals below the desirable weight comprised $2.5 \% \quad(n=32)$ of the sample, while those with normal weight accounted for $41.7 \%(n=528)$ of the subjects included in the study. Table 1 shows the prevalence of individuals underweight, with normal weight, overweight and obese according to the variables selected for comparison

\section{DISCUSSION}

Considering the data of the latest research on frequency and sociodemographic distribution of risk and protective factors for chronic diseases in Brazil ${ }^{14}$, held in 2014, the results of the categorization of study participants according to BMI suggests that this population has a lower prevalence of overweight when compared to the general population, however, there is a higher prevalence of obesity.

While the prevalence of overweight in the general population is estimated at $52.5 \%{ }^{14}$, our study found $34.8 \%(n=441)$. As for obesity, the data estimated for the general population are of a prevalence of $17.9 \%{ }^{14}$ while in this study, participants had a prevalence of obesity of $21 \%(n=266)$.

The results of this study can be compared with another ${ }^{9}$, in which by studying the physical multi-morbidity patterns among people with mental disorders in London, UK, was found a prevalence of overweight and obesity of $32.2 \%$ and $27.5 \%$ respectively. Another author ${ }^{11}$ compared a young population of people with mental disorders to the general population in Sydney, Australia, and found a similar perspective. The prevalence of overweight among users of mental health services compared to the general population was lower $(18.7 \%$ and $25.1 \%$ respectively) and the prevalence of obesity among people with mental disorders was higher than in the general population (12\% and $9 \%$ respectively).

In addition to the perspective that individuals living with mental disorders have mortality rates two to three times higher than the general population $^{7}$ and a reduced life expectancy, between 10 and 30 years $^{8}$, there is the necessity for advance on researches about overweight and obesity in this population. Previous studies point to the relationship between overweight and obesity among users of mental health services with cardiovascular problems ${ }^{11}$, metabolic syndrome ${ }^{15}$ and multiple physical comorbidities. In this sense, this study contributes to this discussion by indicating, for example, the highest prevalence of obesity in participants who reported hypertension (32.97\% $\mathrm{n}=90)$ and diabetes $(36.36 \% \quad \mathrm{n}=40)$. Apart from the fact that individuals living with a mental disorder are a 


\section{JOURNALOF \\ NURSING \\ M०HEALTH}

population at risk for obesity, this fact can also point out that this situation is favorable for expression of other comorbidities in health. From this perspective, a research ${ }^{9}$ indicates that individuals with mental disorders have 2,08 more chance of presenting hypertension, and are 3,51 times more likely to manifest diabetes.

An early study ${ }^{3}$ found that users of mental health services have several other health needs beyond the psychological sphere. However, as seen by one other research ${ }^{4}$, there is a difficulty of the subject to transit between other health services in the network offered by the Unified Health System. Together with the results of this study, these findings are worrisome as that way we have a population that despite posing risks for important health disorders, may not have appropriate assistance.

Thus, it is necessary to sensitize both professionals from Centers for Psychosocial Care as from other services of the Psychosocial Care Network, in particular the units of the Family Health Strategy, on the need for joint actions in the care of individuals with mental disorders in their complexity and in fighting obesity through strategies that work in predisponent factors of this condition, among which: low rate of physical activity and unhealthy diets. ${ }^{10}$ It should be noted that a previous study ${ }^{16}$ conducted in the country has already pointed to the feasibility of adopting physical activities as part of the treatment of users of Centers for Psychosocial Care.

In order to initiate discussions in this regard, an interesting strategy may be to identify the profile of the
ISSN 2236 - 1987

subjects most affected by obesity. This study contributes in this discussion as it identifies that higher prevalence of obesity was observed in females (23.78\% $\mathrm{n}=171)$, aged between 31 and 45 years $(25.87 \% n=134)$ and diagnosed with bipolar disorder $(31.25 \% \mathrm{n}=45)$.

Although a limitation of this study is to rely only on self-reported data, so that the data used to calculate the BMI of the participants as well as other information can be more susceptible to bias, an earlier study on the validity and implications for data analysis of self-reported weight and height to determine the nutritional status of adults 17 indicates that through this type of data it is possible to get a very accurate view of reality.

Besides this perspective, it can be said that one of the strengths of this study is the fact that it stands against a lack of more deep studies on the prevalence of overweight and obesity of individuals living with mental disorders in the country, meaning this study can be an important tool in the proposition of more rigorous studies on the theme.

\section{CONCLUSIONS}

Users of Centers for Psychosocial Care in southern Brazil accessed by this study had a higher prevalence of obesity $(21 \% n=266)$ than the general population in the country. Higher prevalence of obesity was observed in females $(23,7 \% n=171)$, aged between 31 and 45 years $(25,8 \% n=134)$, and diagnosed with bipolar disorder $(31,2 \%$ $n=45$ ). Considering the risks of this situation for the manifestation of other health problems, it is necessary for health services that are part of the Psychosocial Care Network to be 


\section{NURSING \\ AND}

ISSN 2236 - 1987

the evidence. BMC psychiatry. 2015;15(55):1-13.

8. Cook JA, Razzano LA, Swarbrick MA, Jonikas JA, Yost C, Burke L, Steigman $P J$, et al. Health risks and changes in self-efficacy following community health screening of adults with serious mental illnesses. PLos one. 2015 abr;10(4):1-15.

9. Woodhead C, Ashworth M, Schofield $P$, Henderson $M$. Patterns of physical co-/multi-morbidity among patients with serious mental illness: a London borough-based cross-sectional study. BMC fam pract. 2014;15(117):1-9.

10. Bartels SJ, Pratt SI, Aschbrenner KA, Barre LK, Naslund JA, Wolfe R, et al. Pragmatic replication trial of health promotion coaching for obesity in serious mental illness and maintenance of outcomes. Am j pychiatry. 2015 abr;172(4): 344-52.

11. Scott EM, Hermens DF, White D, Naismith JG, Whitwell BG, Glozier N, et al. Body mass, cardiovascular risk and metabolic characteristics of young persons presenting for mental healthcare in Sydney, Australia. BMJ open. 2015 out;5:1-8.

12. Brasil. Conselho Nacional de Saúde. Resolução $n^{\circ} 196$, de 10 de outubro de 1996. Aprova normas regulamentadoras de pesquisas envolvendo seres humanos. Brasília; 1996.

13. Brasil. Conselho Nacional de Saúde. Resolução $n^{\circ}$ 466, de 12 de dezembro de 2012. Aprova normas regulamentadoras de pesquisas envolvendo seres humanos. Brasília; 2013.

14. Brasil. Ministério da Saúde. Secretaria de Vigilância em Saúde. 


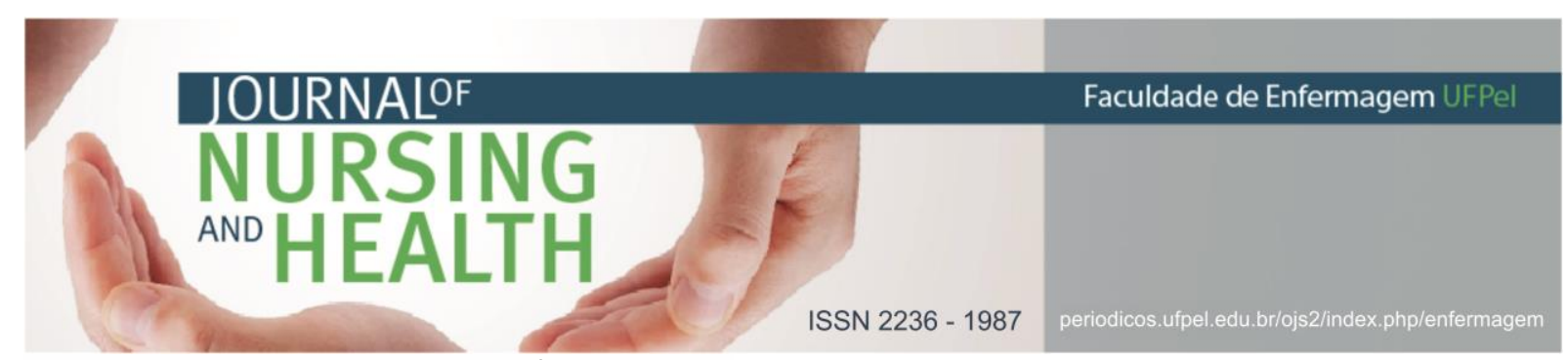

Departamento de Vigilância de Doenças e Agravos não Transmissíveis e Promoção da Saúde. Vigitel Brasil 2014. Brasília; 2015.

15. Gutiérrez-Rojas L, Azanza JR, Bernardo M, Rojo L, Mesa F, MartinezOrtega JM. Prevalence of metabolic syndrome in spanish patients with schizophrenia and overweight. The CRESSOB Study. Actas esp psiquiatr. 2014;42(1):9-17.

16: Adamoli AN, Azevedo MR. Padrões de atividade física de pessoas com transtornos mentais e de comportamento. Ciênc saúde coletiva. 2009;14(1):243-51.

17. Duca GFD, González-Chica DA, Santos JV, Knuth AG, Camargo MBJ, Araújo CL. Peso e altura autorreferidos para determinação do estado nutricional de adultos e idosos: validade e implicações em análise de dados. Cad saúde pública. 2012 jan;28(1):75-85.

Data de submissão: 10/03/2016

Data de aceite: 07/10/2017

Data de publicação: 26/12/2017 